\title{
Primary and secondary thickening in the stem of Cordyline fruticosa (Agavaceae)
}

\author{
MARINA B. CATTAI and NANUZA L. DE MENEZES \\ Instituto de Biociências, Universidade de São Paulo \\ Rua do Matão, 277, Cidade Universitária, Butantã, 05508-090 São Paulo, SP, Brasil \\ Manuscript received on March 4, 2010; accepted for publication on May 5, 2010
}

\begin{abstract}
The growth in thickness of monocotyledon stems can be either primary, or primary and secondary. Most of the authors consider this thickening as a result of the PTM (Primary Thickening Meristem) and the STM (Secondary Thickening Meristem) activity. There are differences in the interpretation of which meristem would be responsible for primary thickening. In Cordyline fruticosa the procambium forms two types of vascular bundles: collateral leaf traces (with proto and metaxylem and proto and metaphloem), and concentric cauline bundles (with metaxylem and metaphloem). The procambium also forms the pericycle, the outermost layer of the vascular cylinder consisting of smaller and less intensely colored cells that are divided irregularly to form new vascular bundles. The pericycle continues the procambial activity, but only produces concentric cauline bundles. It was possible to conclude that the pericycle is responsible for the primary thickening of this species. Further away from the apex, the pericyclic cells undergo periclinal divisions and produce a meristematic layer: the secondary thickening meristem. The analysis of serial sections shows that the pericycle and STM are continuous in this species, and it is clear that the STM originates in the pericycle. The endodermis is acknowledged only as the innermost layer of the cortex.
\end{abstract}

Key words: pericycle, collateral leaf traces, concentric cauline bundles.

\section{INTRODUCTION}

Cordyline fruticosa is an arborescent monocotyledon, formerly known as C. terminalis, and for a long time it was considered part of the Agavaceae family (Brummitt 1992). Dahlgren et al. (1985) included the genus in the Asteliaceae family and, currently, authors such as Conran (1998) and Judd et al. (1999) considered it to be a taxon of the Lomandraceae family. In the International Plant Name Index (Stevens 2001) it is listed under Agavaceae. One of the features of this genus according to Stevenson (1980), Stevenson and Fisher (1980), Diggle and DeMason (1983), DeMason and Wilson (1985) and Rudall (1995), is that its stem has primary thickening due to PTM activity followed by a secondary thickening due to STM activity. These authors have different

Correspondence to: Nanuza Luiza de Menezes

E-mail: nanuzalm@usp.br opinions regarding the continuity between the PTM and STM both in Cordyline fruticosa and other species of Asparagales.

Since the nineteenth century, researchers have had different interpretations over the origin of primary and secondary thickening of the stem among the monocotyledons, especially for plants with rhizomes, corms and bulbs. However, everyone agrees, including current researchers, with one observation: the primary and secondary thickenings occur at the limit between the cortex and vascular cylinder of the stem. Thus, for example, what Schleiden (1842) called "cambium", was called "périméristème" by Guillaud (1878), and "couche dictiogène" (root generating layer) by Mangin (1882). The authors Guillaud (1878) and Mangin (1882) refer to the large number of names given by anatomists who preceded them. 
Some studies that stand out from the first half of the twentieth century are Priestley and North (1922) who referred to "pleurome plus endoderm", Skutch (1932) - to a "cambium-like meristem" and "fugacious cambium" (ephemeral cambium), Helm (1936) - to "a ring meristem", Cheadle (1937) - to a "cambium zone", also referred to by Chakraverti (1939) as "fugacious cambium" until Ball (1941), who attributed the primary thickening in monocot stems to a "primary thickening meristem". This denomination by Ball was referred to by Esau (1943), but Krauss (1948) still referred to a “dyctiogenous layer" similar to Mangin (1882).

It was in the second half of the twentieth century that the most important studies to be consistent with the presence of this meristem, abbreviated as PTM, in many monocotyledons especially the ones bearing rhizome, corm and bulb. Among these authors DeMason (1979a, b), stand out with her study of Allium cepa, described the PTM as a meristematic zone with tangentially flattened cells in the region between the inner cortex and the peripheral region of the vascular cylinder, and notes its resemblance to a cambium, and assumed that the PTM was responsible for the primary thickening of the stem and the formation of adventitious roots. However, Zimmermann and Tomlinson (1965, 1967, 1969) disputed the term, suggesting the existence of a histologically well-defined region, that would be the site of differentiation of vascular bundles and responsible for expanding the cortex's peripheral region. These authors termed this region "meristem cap" and stated that scattered strands of procambium in the meristem produce internal vascular bundles, in the formation of the vascular cylinder, and external bundles - the leaf traces.

In studies with Allium cepa, DeMason (1979a, b) also showed that the PTM is a meristem with bidirectional function, and periclinal divisions produce parenchymal cells centrifugally (to form the inner cortex), and vascular bundles centripetally (to form the vascular system). It is important to point out that the author demonstrated that in the interior of the meristematic layer, in regions far from the apex, there is a row of thickened cells, which the author called "the endodermoid layer" because it is continuous with the endodermis of adventitious roots coming out of that bulb.
Rudall's (1991) important review on PTM discusses many aspects such as concepts, distribution and structure. The author makes it clear that most researchers who refer to PTM admit that it is located in the same position as the pericycle, forms adventitious roots and is responsible for the vascular connections between stem and root and stem and leaf. For some authors, this meristem's activity is only centripetal (forming vascular bundles) for others, it is only centrifugal (forming part of the cortex) and for others (the majority), the activity is both centripetal and centrifugal, forming vascular bundles and part of the cortex (Rudall 1991). Recently, Menezes et al. (2005) and Lima and Menezes (2009) presented another version for primary thickening in monocotyledons. For these authors, the only tissues responsible for this thickening are the pericycle and endodermis, the latter with the same meristematic activity that it has in the root.

The authors emphasize the importance of the work of Williams (1947), which demonstrates that the origin of the cortex radiated from the roots of gymnosperms, paleoherbs, monocotyledons and eudicotyledons, by action of an endodermis with meristematic activity, and this activity was also demonstrated by Van Fleet (1961). Menezes et al. (2005) demonstrated the meristematic activity of the endodermis not only in the root and stem, but also in the leaf.

For these authors, the pericycle that originates in the procambium produces vascular tissues in a centripetal fashion; and the endodermis, which originates from the fundamental meristem forms part or all of the cortex. The same authors completely deny the existence of the PTM, in line with researchers of the nineteenth century (particularly Van Tieghem 1886, 1898), also making it clear that only the pericycle forms lateral roots in roots, and adventitious roots in the stem.

The objective of this study was to determine how primary growth takes place in Cordyline fruticosa and how it forms the secondary thickening meristem in such species.

\section{MATERIALS AND METHODS}

Specimens of Cordyline fruticosa (L.) Chevalier (original from Asia) were collected from the gardens of the Institute of Biosciences, University of São Paulo (SPF 
79573). Ripe fruits were also collected and used for the removal and planting of seeds.

The stem samples were fixed in FAA (formaldehyde 37\%, glacial acetic acid, ethanol 50\%1:1:18 v/v) (Johansen 1940) for 48 hours, followed by dehydration in ethanol series up to $70 \%$ ethanol.

The study was carried out using histological crosssections in different portions of the aerial stem, obtained with a rotary microtome. To obtain the cuttings with a rotary microtome, the material was embedded in paraffin using methods described in Kraus and Arduin (1997) and were previously dehydrated in tertiary butyl series (Johansen 1940).

In the serial sections in paraffin, astra blue dye and safranin (Bukatsch 1972), and crystal violet and orange G (Purvis et al. 1964) were used. The histological slides were assembled with synthetic mounting medium (Entellan).

\section{RESULTS}

In the study that used serial sections of various stages of development of Cordyline fruticosa, it was possible to observe the growth of the aerial stem from the formation of primordial leaves until the formation of secondary tissues.

In a region situated about $2 \mathrm{~mm}$ from the apex (Figs. 1-3), tissues that were differentiated and in differentiation were observed. In Figure 2, the pericyclic region can be seen (lighter in color), consisting of cells smaller than the parenchyma cells of the stem cortex and vascular cylinder, more clearly shown in Figure 3. It can also be observed in Figures 2 and 3 that the bundles in the central region comprising the vascular system are of two types: colateral, corresponding to leaf traces and with already differentiated protophloem and protoxylem, and metaxylem and metaphloem undergoing differentiation; and concentric, which are cauline bundles and have only differentiating metaphloem and metaxylem. The two types of bundles are best viewed in detail in Figures 3 and 5.

The pericyclic region, whose cells undergo irregular divisions for the formation of new bundles, can be seen in Figures 4-6. One can also see, in Figure 6, cauline bundles recently formed by the pericycle, but still undergoing differentiation.
In cross sections, taken approximately $4 \mathrm{~mm}$ from the apex (Figs. 7-9), it is possible to observe the initial formation of the secondary thickening meristem. One can see the pericyclic region (Figs. 8 and 9) as a region of cells that are smaller and stain less intensely. These cells periclinally divide producing cells that will form the secondary thickening meristem (STM).

The STM is in activity, observed by the presence of secondary cauline bundles, secondary cortex and cells undergoing periclinal divisions and forming new bundles, as shown in Figures 10 and 11.

\section{DISCUSSION}

In this study, it was observed that the procambial bundles can be of two types: collateral, with protoxylem, metaxylem, protophloem and metaphloem; and concentric, with only metaxylem and metaphloem, similar to the observations of Velloziaceae made by Menezes (1971). In Velloziaceae, which presents only collateral bundles, the author found that the bundles that differentiated protoxylem and protophloem (as well as metaphloem and metaxylem) were leaf traces, and the bundles formed only by metaphloem and metaxylem were cauline bundles. The presence of protoxylem and protophloem in leaf traces was also reported by Zimmermann and Tomlinson (1967) and in other monocotyledons.

In Cordyline fruticosa, the cauline bundles, as seen above, are concentric and devoid of protoxylem and protophloem. While authors such as Diggle and DeMason (1983), Stevenson and Fisher (1980) and DeMason and Wilson (1985) attribute the formation of concentric bundles to PTM, this study found that, in the beginning, these concentric bundles are produced by the procambium and, afterwards, the pericycle is the meristematic tissue that provides continuity to the formation of these bundles, in the same way as was reported by Menezes et al. (2005) in several families of monocotyledons and in Scleria (Cyperaceae) by Lima and Menezes (2009).

Any textbook shows that, in the root, the procambium produces the primary xylem, primary phloem and the pericycle, with the pericycle being the outermost layer of the vascular system adjacent to the endodermis (Esau 1965, Fahn 1989, Mauseth 1995, Raven et al. 1999). However, in the stem, only Menezes et al. (2005) demonstrated, in two genera of Cyperaceae 


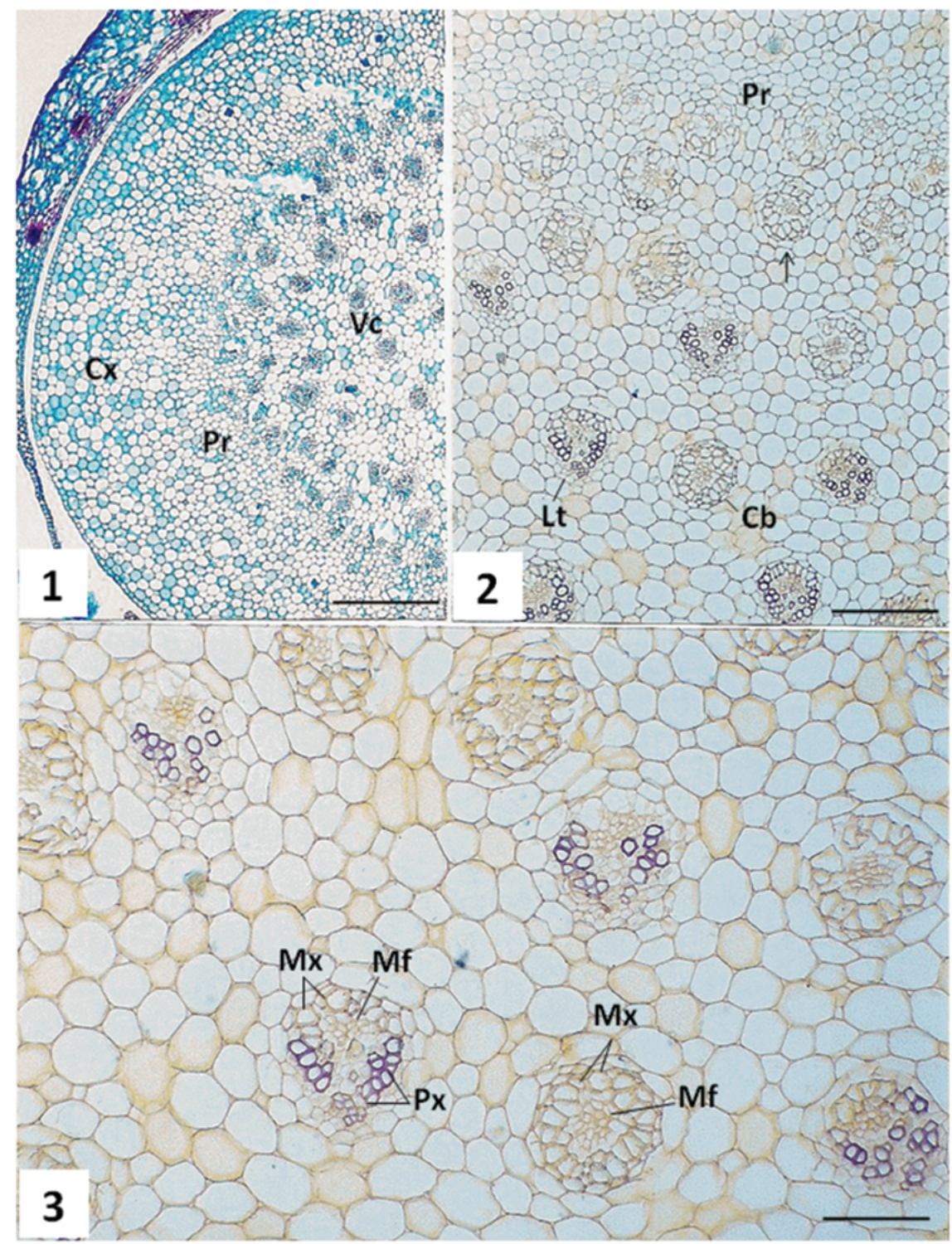

Fig. 1-3 - Cross sections at the stem apex of Cordyline fruticosa. Figs. 1 - The pericyclic region (Pr) is formed by smaller cells between the cortex $(\mathrm{Cx})$ and the vascular cylinder $(\mathrm{Vc})$ Figs. 2 - Leaf traces $(\mathrm{Lt})$, which are collateral bundles, and concentric cauline bundles $(\mathrm{Cb})$; new bundles appear from the pericycle; the arrow indicates externally the procambium bundles, a pericyclic concentric cauline bundle. Fig. 3 - Concentric cauline bundles of procambial origin formed by metaxylem (Mx), metaphloem (Mf), and the leaf traces formed by metaxylem, metaphloem, protoxylem (Px) and protophloem. The bars correspond to $400 \mu \mathrm{m}, 200 \mu \mathrm{m}$ and $100 \mu \mathrm{m}$, respectively.

(Cyperus and Lagenocarpus), one species of Rapateaceae (Cephalostemon riedelianus) and one species of Zingiberaceae (Zingiber officinale), that the pericycle, adjacent to the endodermis, is the layer that generates vascular tissues. These observations were confirmed by Lima and Menezes (2009) in species of Scleria (Cyperaceae) from Serra do Cipó (MG).
In these genera, due to the continuity between the tissues of adventitious roots formed in the rhizome and the tissues of the same rhizome, it was possible to locate the endodermis and to note meristematic activity of this tissue in the stem, as in the root. Once the endodermis was detected, the authors showed that the layer adjacent to it is the pericycle, which is also the genera- 


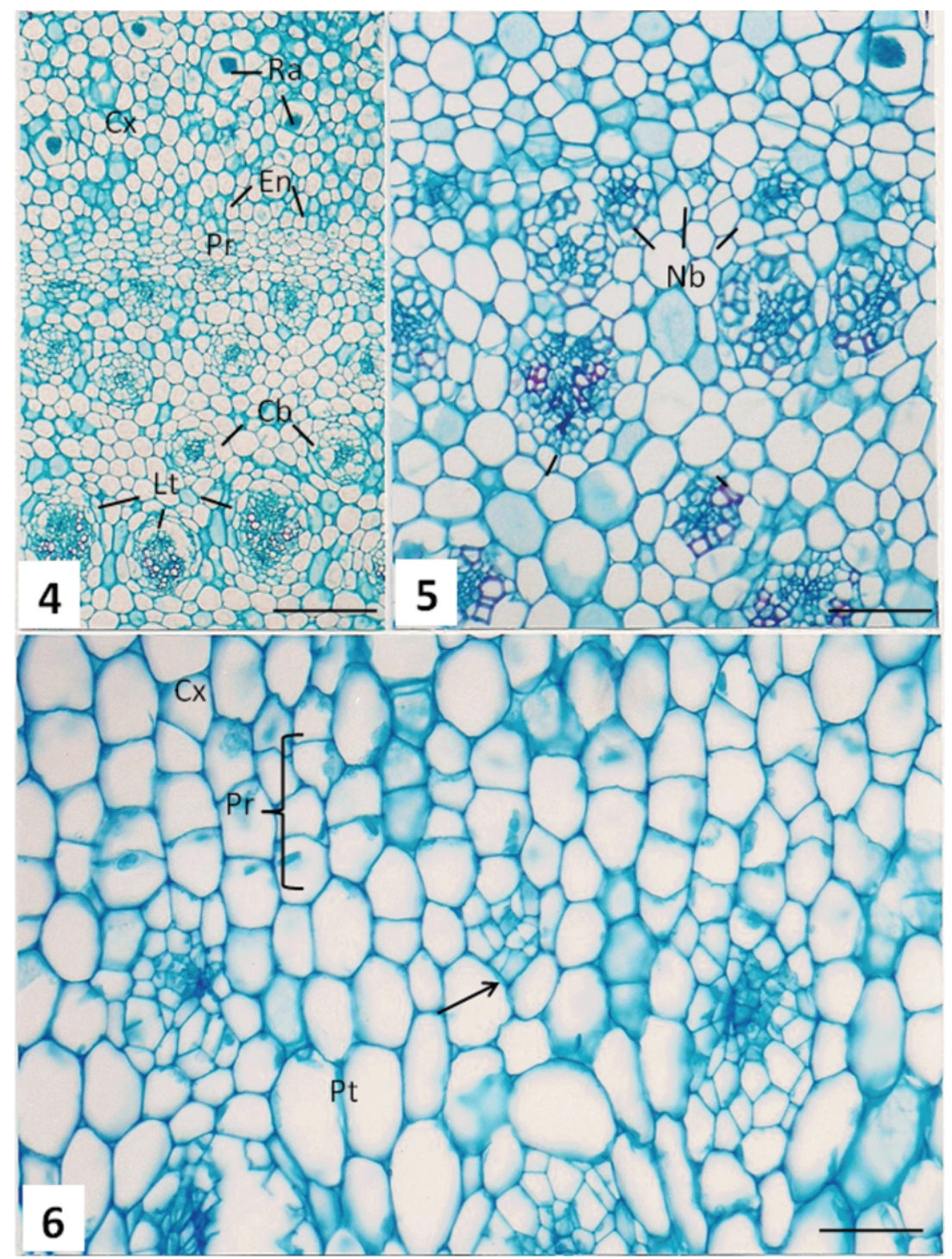

Figs. 4-6 - Cross sections at the stem apex of Cordyline fruticosa. Fig. 4 - Cortex (Cx) with raphides (Ra), leaf traces (Lt), cauline bundles (Cb) and pericyclic region (Pr). Fig. 5 - New bundles $(\mathrm{Nb})$ originating from the pericycle by irregular divisions. Fig. 6 - Recently formed new bundles in the pericyclic region, one of them (arrow) still partially included in the pericycle. En - endodermis; Pt - pith. The bars correspond to $200 \mu \mathrm{m}$, $100 \mu \mathrm{m}$ and $50 \mu \mathrm{m}$, respectively.

tor of vascular tissues in sequence to the activity of the procambium. The same authors do not believe that, unlike other vascular plants, there is a special meristem in monocotyledons and refer to what nineteenth century researchers postulated, such as Van Tieghem (1886, 1898), that only the pericycle forms lateral roots, in roots, and adventitious roots in the stem.

In Cordyline fruticosa, as there was no adventitious root coming out and also because Casparian strips and suberin were not detected in the endodermic cells, this was only considered a possibility by Van Fleet (1961), i.e., as the innermost layer of the cortex.

More recently, Menezes et al. 2005, 2008 and Lima and Menezes 2009, working with stems of different monocotyledon families, demonstrated that the stem endodermis is detected by the continuity with the endodermis of the root, by the presence of Casparian strips, by the presence of reinforcements in $u$ or in $\mathrm{o}$, or alter- 

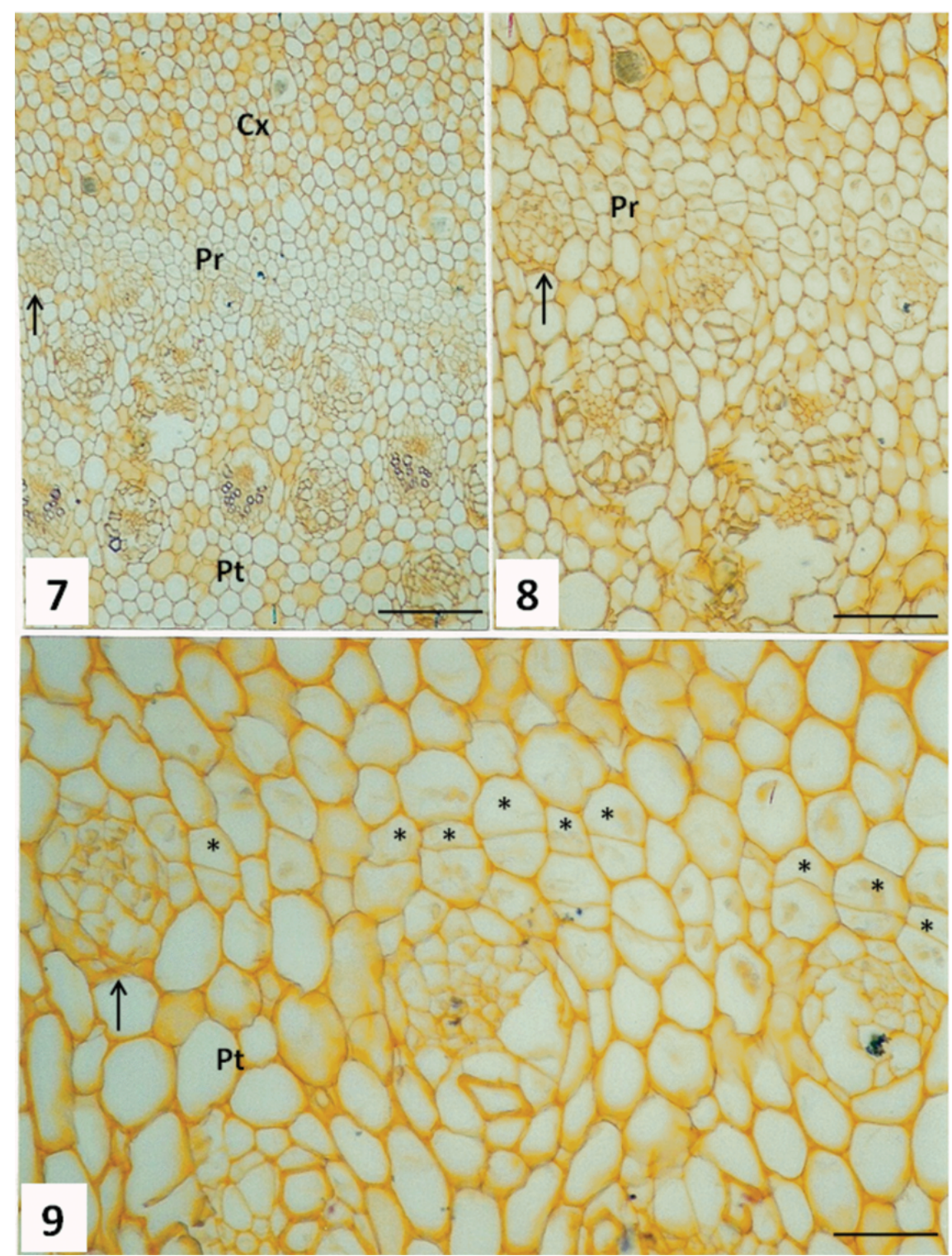

Figs. 7-9 - Cross sections at the stem apex of Cordyline fruticosa. The pericyclic region (Pr) shows periclinal divisions; also note a bundle (arrow) still of pericyclic origin. Asterisks indicate recently-divided pericyclic cells. $\mathrm{Cx}-$ cortex; Pt - pith. The bars correspond to $200 \mu \mathrm{m}, 100 \mu \mathrm{m}$ and $50 \mu \mathrm{m}$, respectively.

natively, by the presence of starch (starch sheath). The authors also demonstrated that the pericycle is the layer that generates vascular tissue, and the endodermis, with meristematic activity, the generator of radiated cortex in the root and stem, and in part of the leaf mesophyll. In these studies, the aforementioned theory was demonstrated in the following families: Hypoxidaceae ( $\mathrm{Hy}$ poxis and Curculigo), Cyperaceae (Scleria) Commelinaceae (Commelina, Tradescantia and Floscopa), Rus- caceae (Ruscus and Ophiopogon), Zingiberaceae (Zingiber and Kaempferia), Cannaceae (Canna), Hemerocallidaceae (Hemerocallis), Asphodelaceae (Bulbine) and Xyridaceae (Xyris).

The previous results (Menezes et al. 2005, Lima and Menezes 2009) and those presented here are similar to those postulated by Zimmermann and Tomlinson (1967), which refer to the existence of a "cap meristem", because, for these authors the procambium would 


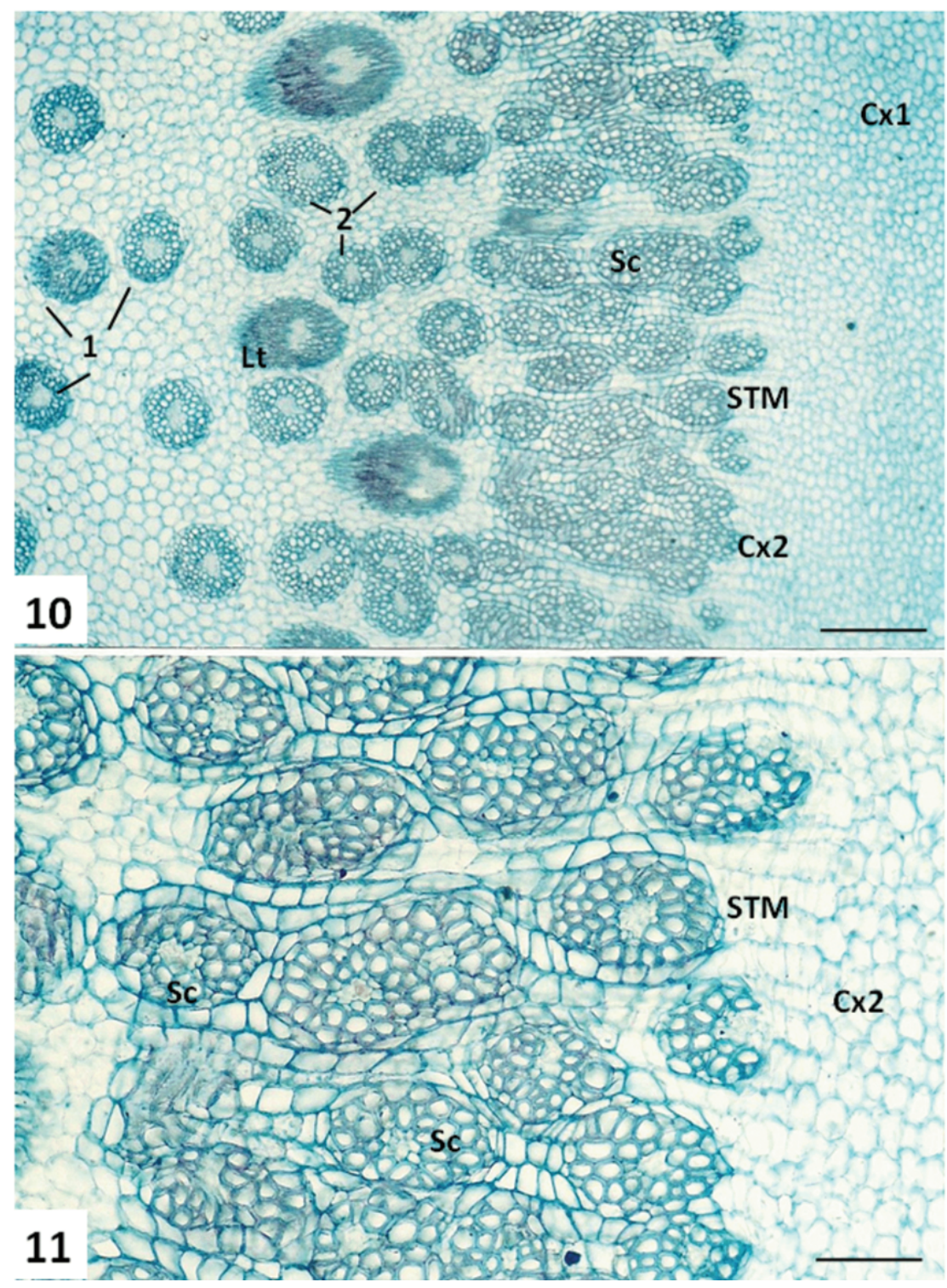

Figs. 10-11 - Cross-sections from the region where secondary thickening meristem (STM) is in activity. Fig. 10 - Primary bundles of procambial origin indicated by (1); of pericyclic origin, (2) and secondary bundles ( $\mathrm{Sc})$. Also note, the primary cortex (Cx1) and, secondary cortex (Cx2) with radiating rows of cells, better observed in Fig. 11. Lt - leaf trace. The bars correspond to $100 \mu \mathrm{m}$ and $50 \mu \mathrm{m}$, respectively.

form the bundles within the vascular cylinder, including the periphery of the vascular cylinder and externally to them. Therefore, Zimmermann and Tomlinson (1967) did not mention the presence of a pericycle in the stem. This differs, however, in the assumption by Menezes et al. (2005) and Lima and Menezes (2009) who claim that, under the apical meristem, the procambium in the periphery of the vascular system is juxtaposed with the endodermis to produce the pericycle. In addition, Tom- linson (1969) only admits the existence of an endodermis in the stem if it has Casparian strips. Even referring to the layer of the stem as being in continuity with the endodermis of adventitious roots he called it "endodermoid" layer, i.e., similar to the endodermis, in the same way as in DeMason (1979a).

As presented in this work, the pericycle gives rise to new bundles of the vascular system through irregular divisions and, after a period of activity by forming new 
bundles (about $4 \mathrm{~mm}$ from the apex), the pericycle starts to divide periclinally to form the STM. Thus, the formation of STM is perfectly continuous with the pericycle (referred by the other authors as PTM) because, in the same level where there is the formation of new bundles, in the pericycle, there are periclinal divisions that lead to the formation of STM in Cordyline fruticosa.

The irregular pattern of divisions that are observed in the C. fruticosa pericycle was also detected by DeMason (1979a, b) in a study of Allium cepa in a tissue that she called PTM.

There are many differences among authors regarding the continuity between the PTM and STM. Some authors, for example, Stevenson and Fisher (1980), once studying the development of Cordyline terminalis, state that the PTM and STM are longitudinally discontinuous.

Stevenson (1980) noted that, in Beaucarnea recur$v a t a$, the two meristems are continuous at the beginning of the growth and discontinuous in adult stages. The author attributes this posterior discontinuity to the internodal growth that occurs during development.

On the other hand, other authors believe that the PTM and STM are longitudinally continuous, such as DeMason and Wilson (1985) who observed it in Cordyline terminalis and disagreed with Stevenson and Fisher (1980). Likewise, Diggle and DeMason (1983), in studies with Yucca whipley, observed that the PTM and STM are also longitudinally continuous. These authors showed that the meristems are histologically and functionally similar in many aspects.

This study showed that the pericycle is still forming new bundles and that its cells already present periclinal divisions to form the STM. According to Esau (1943) and Lindinger (1908 apud Esau 1943), in all the monocotyledons, the primary and secondary thickenings are continuous and if there is an apparently interruption between the meristems (which he also called primary and secondary), this occurs because the meristem, after completing primary growth, becomes quiescent for a while, then returns to activity, in order to produce secondary tissues.

Diggle and DeMason (1983) also showed that the primary vascular bundles are collateral and the secondary are amphivasal. However, as observed in this work, and already reported by Lima and Menezes (2009), the procambium forms leaf traces (collateral) and cauline bundles (concentric). And that, in continuity to the primary thickening in Cordyline fruticosa, the pericycle also replaces the procambium and forms new cauline bundles, i.e., concentric bundles formed only by metaxylem and metaphloem.

According to Menezes et al. $(2005,2008)$ and Lima and Menezes (2009), the pericycle forms only cauline bundles and only the procambium forms leaf traces, unlike Zimmermann and Tomlinson (1967).

When the STM is established, it also produces concentric but secondary bundles. With the STM activity, the secondary cortex is formed outwards and concentric bundles inwards. Interestingly, secondary cauline bundles form in the STM in a similar fashion to how cauline bundles form in the pericycle, i.e., by dividing irregularly, forming amphivasal concentric bundles. It is our intention to discuss this topic in a future study.

\section{ACKNOWLEDGMENTS}

The authors wish to thank the collaboration of Msc. Paula Maria Elbl and Biol. Tássia Cristina dos Santos in the manufacture of boards, Fundação de Amparo à Pesquisa do Estado de São Paulo (FAPESP) and Conselho Nacional de Desenvolvimento Científico e Tecnológico $(\mathrm{CNPq})$ for financial support.

\section{RESUMO}

O crescimento em espessura do caule de monocotiledônea pode ser primário, ou primário e secundário. A maioria dos autores consideram o espessamento resultante do MEP (Meristema de Espessamento Primário) e do MES (Meristema de Espessamento Secundário). Há divergências de qual seria o meristema responsável pelo espessamento primário. Em Cordyline fruticosa o procâmbio forma feixes vasculares de dois tipos: traços foliares colaterais (com proto e metaxilema e proto e metafloema), e feixes caulinares concêntricos (com metaxilema e metafloema). O procâmbio também forma o periciclo, a camada mais externa do cilindro vascular, constituída por células menores e menos coradas que se dividem irregularmente, formando novos feixes vasculares. O periciclo dá continuidade à atividade procambial, originando somente feixes concêntricos. Concluiu-se ser o periciclo responsável pelo espessamento primário desta espécie. Mais distante do ápice as 
células pericíclicas passam a sofrer divisões periclinais originando o Meristema de Espessamento Secundário. A análise dos cortes seriados mostra que o periciclo e o MES são contínuos nesta espécie, ficando claro que o periciclo origina o MES. A endoderme é reconhecida, apenas, como a camada mais interna do córtex.

Palavras-chave: periciclo, traços foliares colaterais, feixes caulinares concêntricos.

\section{REFERENCES}

BALL E. 1941. The development of the shoot apex and of the primary thickening meristem in Phoenix canariensis Chaub., with comparisons to Washingtonia filifera Wats. And Trachycarpus excels Wendl. Am J Bot 28: 820-832.

BRUMMITT RK. 1992. Vascular plant families and genera. Royal Botanic Gardens, Kew, 820 p.

BUKATSCH F. 1972. Bemerkungen zur DoppelfärbungAstrablau-Safranin. Mikrokosmos 61: 255.

Chakraverti DN. 1939. The occurrence of fugacious cambium in the rhizome of Curcuma longa L. Philipp J Sci 69: 191-195.

CHeAdLE VI. 1937. Secondary growth by means of a thickening ring in certain Monocotyledons. Bot Gaz 98: 535555 .

CONRAN JG. 1998. Lomandraceae. In: KUBITZKI K (Ed), The Families and Genera of Vascular Plants. Vol. 3. Flowering Plants. Monocotyledons: Lilianae (except Orchidaceae). Springer Verlag, Berlin 3: 354-365.

Dahlgren R, Clifford HT And Yeo PF. 1985. The families of the monocotyledons. Springer-Verlag, Berlin, $520 \mathrm{p}$.

DEMASON DA. 1979a. Function and development of the primary thickening meristem in the Monocotyledon, Allium cepa L. Bot Gaz 140: 51-66.

DEMASON DA. 1979b. Histochemistry of the primary thickening meristem in the vegetative stem of Allium cepa $\mathrm{L}$. Am J Bot 66: 347-350.

DEMASON DA AND WILSON MA. 1985. The continuity of primary and secondary growth in Cordyline terminalis (Agavaceae). Can J Bot 63: 1907-1913.

Diggle PK And Demason DA. 1983. The relationship between the primary thickening meristem and the secondary thickening meristem in Yucca whipplei Torr. II. Ontogenetic relationship within the vegetative stem. Am J Bot 70: $1205-1216$.
ESAU K. 1943. Origin and development of primary vascular tissues in seed plants. Bot Rev 9: 125-206.

ESAU K. 1965. Plant anatomy. $2^{\text {nd }}$ ed., J Wiley \& Sons, New York. $735 \mathrm{p}$.

FAHN A. 1989. Plant anatomy. $3^{\text {rd }}$ ed., Pergamon Press, Oxford, London. 611 p.

Guillaud A. 1878. Rechersches sur l'anatomie comparée et le developpement des tissues de la tige dans les monocotylédones. Ann Sci Nat Bot Ser 6: 1-176.

Helm J. 1936. Das Erstarkungswachstum der Palmen und einiger anderer Monokotylen, zugleich ein Beitrag zur Frage dês Erstarkungswachstums der Monokotylen überhaupt. Planta 26: 319-364.

JoHANSEn DA. 1940. Plant microtechnique. McGraw-Hill, New York. 523 p.

Judd Ws, Campbell CS, Kellogg EA and Stevens PF. 1999. Plant systematics: A phylogenetic approach. Sinauer, Sunderland, Massachusetts. $464 \mathrm{p}$

Kraus JE And Arduin M. 1997. Manual Básico de Métodos em Anatomia Vegetal. EDUR (Ed. Universidade Rural), Seropédica, RJ, 198 p.

KRAUSS BH. 1948. Anatomy of the Vegetative Organs of the Pineapple, Ananas comosus (L.) Merr Merr. I. Introduction, Organography, the Stem, and the Lateral Branch or Axillary Buds. Bot Gaz 110: 159-217.

Lima VFGP AND Menezes NL DE. 2009. Morpho-Anatomical Analysis of the Rhizome in Species of Scleria Berg. (Cyperaceae) from Serra do Cipó (MG). Braz Arch Biol Technol 52: 1473-1483.

MANGIN L. 1882. Origine et insertion des racines adventives et modifications corrélatives de la tîge chez les monocotylédones. Ann Sci Nat Bot 14: 216-363.

Mauseth JD. 1995. Plant anatomy. Benjamin/Cumming Publishing Company, Menlo Park.

Menezes NL DE. 1971. Traqueídes de transfusão no gênero Vellozia Vand. Cien Cult 23: 389-409.

Menezes NL de, Silva DC, ARruda RCO, Melo-DePinna GF, Cardoso VA, Castro NM, Scatena VL AND SCREMIN-Dias E. 2005. Meristematic activity of the Endodermis and the Pericycle in the primary thickening in monocotyledons: considerations on the "PTM". An Acad Bras Cienc 77: 259-274.

Menezes NL de, Elbl PM, Silva CG, Garcia AAI, SASAKI KL AND Alves VFG. 2008. Primary thickening in Monocotyledons: Pericycle and endodermis. Escape floral. In: The Fourth International Conference on 
Comparative Biology of the Monocotyledons \& The Fifth International Symposium on Grass Systematics and Evolution. Copenhagen, Denmark. University of Copenhagen. Abstracts, $76 \mathrm{p}$.

Priestley JH And North EE. 1922. Physiological Studies in Plant Anatomy III. The Structure of the Endodermis in Relation to its Function. New Phytol 21: 113-139.

Purvis MJ, Collier DC And Walls D. 1964. Laboratory techniques in botany. Butterworths, London, $371 \mathrm{p}$.

RAVEN PH, EVERT RF AND EICHHORN SE. 1999. Biology of Plants. $6^{\text {th }}$ ed, W.H. Freeman and Company and Worth Publishers, $727 \mathrm{p}$.

RUDALL P. 1991. Lateral meristems and stem thickening growth in monocotyledons. Bot Rev 57: 150-163.

RUDALL P. 1995. New records of secondary thickening in monocotyledons. IAWA J 16: 261-268.

SCHLEIDEN MJ. 1842. Grundzüge der wissenschaftlichen Botanik. Leipzig, 298 p.

SkUTCH AF. 1932. Anatomy of the Axis of the Banana. Bot Gaz 93: 233-258.

Stevens PF. 2001 onwards. Angiosperm Phylogeny Website. Version 9, June 2008.

$<$ http://www.mobot.org/MOBOT/research/APweb/>.

SteVenson DW. 1980. Radial growth in Beaucarnea recurvata. Am J Bot 67: 476-489.

SteVenson DW AND Fisher JB. 1980. The Developmental Relationship between Primary and Secondary Thickening Growth in Cordyline (Agavaceae). Bot Gaz 141: 264-268.
TOMLINSON PB. 1969. III - Commelinales-Zingiberales. In: Anatomy of the Monocotyledons (MetCALFE CR (Ed)), Oxford, Clarendon Press, 446 p.

VAN FLEET DS. 1961. Histochemistry and function of the endodermis. Bot Rev 27: 165-220.

VAn Tieghem PH. 1886. Sur le péricycle. Reponse a M. d'Arbaumont. Soc Bot France Bull 33: 152-153.

VAN TIEGHEM PH. 1898. Éléments de Botanique. I. Botanique Générale. 30. Paris: Masson et Cie. (Eds), 599 p.

Williams BC. 1947. The structure of the meristematic root tip and origin of the primary tissues in the roots of vascular plants. Am J Bot 34: 455-462.

ZIMMERMANN MH AND TOMLINSON PB. 1965. Anatomy of the palm Rhapis excels. I. Mature vegetative axis. J Arnold Arbor 46: 160-180.

ZiMMERMANN MH AND TOMLINSON PB. 1967. Anatomy of the palm Rhapis excels, IV. Vascular development in apex of vegetative aerial axis and rhizome. J Arnold Arbor 48: $122-142$.

ZiMMERMANN MH AND TOMLINSON PB. 1969. The vascular system in the axis of Dracaena fragrans (Agavaceae). 1. Distribution and development of primary strands. J Arnold Arbor 50: 370-383. 